\title{
"Há quanto tempo se põe o sol em espinho? Ruy Belo e o fazer poético que interpela a realidade
}

\author{
Carina Marques Duarte
}

\begin{abstract}
The purpose of this study is to analyze some poems from the book Homem de Palavra[s] (Man of Word [s], author's translation), published in 1969 by Ruy Belo. Aiming, first, at making explicit the author's political agenda and, secondly, identifying the role of two instruments used by poet - metaphor and intertextuality - to form the poem as a answer to the world.
\end{abstract}

Keywords: Ruy Belo; Intertextuality; Metaphor; Political agency.

Resumo: A proposta deste trabalho é analisar alguns poemas do livro Homem de Palavra[s], publicado por Ruy Belo em 1969, objetivando, em primeiro lugar, explicitar a agenda política do autor e, em segundo lugar, identificar o papel de dois instrumentos utilizados pelo poeta - a metáfora e a intertextualidade - para a constituição do poema como resposta ao mundo.

Palavras-chave: Ruy Belo; Intertextualidade; Metáfora; Agência política.

\section{CONSIDERAÇÕES INICIAIS}

Considerado um dos poetas portugueses de produção mais significativa na segunda metade do século XX, Ruy Belo estreou na literatura no ano de 1961 com a obra Aquele Grande Rio Eufrates. No momento em que três correntes estavam em voga na poesia portuguesa, o poeta não aderiu de maneira programática a nenhuma delas - nem à poesia de engajamento político, nem às correntes que preconizavam uma poesia pura, como foi o caso da Poesia Experimental e da Poesia-61. Homem comprometido com o seu tempo, o escritor não encarou o fazer poético apenas como um jogo, uma aventura de linguagem, mas fez dele, também, um meio de questionar as estruturas de poder.

Em "Lírica e Sociedade", Adorno (1983), ao expor a tese de que a universalidade do conteúdo lírico é sempre social, comenta que os conceitos sociais, as ideias, não devem ser trazidos de fora às formações líricas, mas brotar delas mesmas. Além disso, apenas os elementos presentes na forma própria das obras justificam a decisão sobre o que o conteúdo representa socialmente. "Determiná-lo requer, sem dúvida, não só o saber da obra de arte por dentro, como também o da sociedade fora dela" (Ibidem: 194). Desse modo, a construção do sentido a partir da leitura de Homem de Palavra [s] supõe, além da mobilização de diversos textos, o recurso ao contexto no qual a obra foi produzida e ao qual, de certa forma, responde.

1 É doutoranda em Literatura Comparada pela Universidade Federal do Rio Grande do Sul. 


\section{Um momento propício à intervenção da escrita na realidade opressora}

Na década de 60, com o início da Guerra Colonial, intensificaram-se as pressões internacionais sobre o governo português: a hostilidade se dirigia tanto ao regime ditatorial quanto à intervenção armada no ultramar. Entretanto, o regime não via outra saída que não fosse a continuidade da guerra e reprimia de forma severa a menor resistência. Disso nos dão conta, por exemplo, as prisões e violências exercidas contra os estudantes em 1962 e em 1965, e o assalto e encerramento da Sociedade Portuguesa de Escritores².

Com a substituição de Salazar por Marcelo Caetano, não há uma modificação na política em relação à Guerra Colonial. Aliás, o argumento que agora legitima a continuidade do conflito é a necessidade de defender os interesses das populações brancas, as quais o Estado, procedendo à descolonização, não poderia abandonar à sua própria sorte. Assim, não havendo uma mudança de rumo na política, no final da década de 60, como refere Rosas (1998), o que se verifica é uma "avalanche de expectativas, de reivindicações, de desejo de mudança” (Ibidem: 489). A Universidade de Lisboa, desde fins de 1968, recebendo os ares de maio, entra em greve e lutas sucessivas. Eram objetos de contestação o sistema de ensino, os métodos de seleção e os conteúdos programáticos. A isso se somava a denúncia do regime político, do colonialismo e da guerra.

A insatisfação no meio acadêmico teria continuidade em 1969 com a ocupação estudantil do Instituto de Ciências Econômicas e Financeiras, onde durante semanas vigoraram os cursos livres e os textos proibidos do marxismo clássico ou dos neomarxistas. No mesmo ano ocorre uma prolongada greve estudantil em Coimbra, que culmina em violentos confrontos com a Polícia de Segurança Pública e a Guarda Nacional Republicana e em rigorosas punições disciplinares. Fagulhas da revolta dos estudantes logo atingiriam outros setores. Assim seguem-se greves entre os ferroviários, os metalúrgicos, os trabalhadores do ramo têxtil, os bancários e os empregados do comércio.

Mas estes não eram os únicos focos de resistência em Portugal. É preciso referir a insatisfação de um grupo significativo de católicos gerada pelo compromisso da Igreja com o Estado. Tal insatisfação foi acompanhada, já no princípio dos anos 50, por um enfraquecimento da fé religiosa e consequente afastamento da Igreja, especialmente por parte de cidadãos do meio intelectual, que, aliás, eram os mais politicamente atuantes. A perda de uma parcela dos seus membros coincidiu com iniciativas de renovação na Igreja, ainda que minoritárias. Entretanto, tais movimentos de renovação e abertura ao mundo- passaram a ser vigiados pela polícia. Este foi o caso do "Metanoia"3, que, depois de despertar a desconfiança da polícia, foi desautorizado pela Igreja. Também a Revista O Tempo e o Modo, que, desde o início, como menciona Ribeiro (2004), contou com a colaboração de católicos, de pessoas não vinculadas à Igreja e de intelectuais de esquerda, estava relacionada com católicos que romperam com o salazarismo. Tendo em vista o surgimento de uma nova mentalidade na Igreja, evidenciada, por exemplo, pela atenção às questões sociais do país, o Estado deixa de ter nela um ponto de apoio. Importa salientar a relevância da atuação dos intelectuais que foram também "católicos vencidos", como os definiu Ruy Belo, ao reunirem em publicações diversas vozes da intelectualidade que tinham em comum o fato de serem politicamente comprometidos.

Comprometimento está ligado à responsabilidade. E o próprio Ruy Belo (1969) afirma que quanto mais poeta mais responsável. O poeta manteve a coerência com esta posição não apenas no seu fazer poético, mas também na sua participação nos acontecimentos políticos. Em 1960, é nomeado adjunto do Diretor do Serviço da Escolha de Liv-

\footnotetext{
2 Foi encerrada pelo governo e as suas instalações foram assaltadas e saqueadas por legionários, depois da atribuição de um prêmio a Luandino Vieira, naquele momento preso em virtude da sua atuação no movimento de libertação angolano.

3 Atuou no meio cultural através da publicação de cadernos.
} 
ros do Ministério da Educação Nacional, cargo do qual, mais tarde, quando está prestes a ser nomeado diretor, pede demissão. Em 1962, já na Faculdade de Letras, participa da greve acadêmica. Isto - somado ao seu relacionamento com opositores ao regime e à sua candidatura a deputado, em 1969, pela Comissão Eleitoral da Unidade Democrática - é o suficiente para que as suas atividades passem a ser vigiadas.

A produção poética de Ruy Belo certamente não deixaria de ser afetada pelas perturbações da época e pelas vivências do poeta. $\mathrm{O}$ fato, de certo modo, é reconhecido pelo escritor no livro de ensaios $N a$ senda da poesia, quando, perguntado sobre que papel atribui à poesia, afirma que esta deve contribuir para fundar uma sociedade mais justa. Todavia, é contrário ao engajamento como algo determinante do fazer poético: “A função, por mais importante que seja, é exterior ao ser da poesia e não deve entrar nos propósitos nem nos métodos do poeta. No entanto, o poeta é um homem e este é responsável perante a sua consciência e a consciência dos outros" (BELO, 1969: 18). Esta responsabilidade pode ser inferida até mesmo do título Homem de Palavra [s]. Ao tratar do assunto, Gastão Cruz refere que o labor poético de Ruy Belo é o de "um homem de palavras", "alguém para quem a linguagem não é um meio mas um fim [...]" (CRUZ, 1973: 134). Nele há um poeta e, ao mesmo tempo, um homem de palavra trabalhando sobre a linguagem, ou seja, "a autenticidade do poeta é a autenticidade da sua linguagem". E é por meio desta que o escritor, aproveitando-se da polissemia que a caracteriza, revela, em um momento propício à intervenção da escrita na realidade, o seu compromisso ético. Vale enfatizar que as preocupações sociais do poeta não o conduzem ao caminho do poema panfletário. Até porque Ruy Belo acreditava, e nisto, de certo modo, dialoga com Adorno, que a poesia não deveria estar submetida a princípios doutrinários enquanto mecanismos, impostos, exteriores ao seu ser, mas poderia, sim, "recebê-los de dentro como enquadramento da emoção singular" (BELO, 1969: 21). Desse modo, a poesia pode servir como veículo para uma ideia ou conceito, todavia, estes têm de "se humilhar perante o valor material da palavra e sujeitar-se à ação da metáfora" (BELO, 1969: 22).

\section{Metáfora e intertextualidade: dois instrumentos na intensificação do real}

Na obra $A$ metáfora viva, Paul Ricoeur (1983) afirma que interpretar uma obra é desvendar o mundo a que ela se refere. No que diz respeito a Homem de Palavra [s], mais especificamente sobre os poemas pertencentes à seção "Palavra[s] de lugar", podemos identificar, como sugere o título, que os poemas, de modo geral, apontam para a realidade portuguesa da década de 60 . Assim, nos deparamos com a representação de um espaço opressor, com a denúncia do sofrimento, a ironia dirigida aos poderosos e a exposição da decepção e da crise religiosa. O poema que abre o livro - não por acaso intitulado "Literatura Explicativa" - parece ter a função de demonstrar a necessidade da poesia naquele momento e naquele lugar:

O pôr-do-sol em Espinho não é o pôr-do-solnem mesmo o pôr-do-sol é bem o pôr-do-solÉ não morrermos mais é irmos de mãos dadascom alguém ou com nós mesmos anos antesé lermos Leibniz conviver com os Medicisonze quilômetros ao sul de Florençasobre restos de inquietação visível em bilhetes de eléctricoHá quanto tempo se põe o sol em Espinho?Terão visto este sol os liberais no marou Antero de junto da ermida?O sol que aqui se põe onde nasce? A quempassamos este sol? Quem se levanta onde nos deitamos?O pôr-do-sol em Espinho é termos sido felizesé sentir como nosso o braço esquerdoOu melhor: é não haver mais nada mais ninguémmulheres recortadas nas vidraçasoliveiras à chuva homens a trabalharcoisas todas as coisas deixadas a si mesmasNão mais restos de vozes solidão dos vidrosnão mais os homens coisas que pensam coisas sozinhasnão mais o pôr-do-sol apenas pôr-do-sol (BELO, 2004: 257). 
Através de versos livres, sem preocupação com rimas ou sinais de pontuação ${ }^{4}$, são apresentadas duas realidades opostas: o pôr do sol e o pôr do sol em espinho. A primeira estava situada em algum lugar do passado, quando a atenção às coisas simples - ir com alguém de mãos dadas, oliveiras à chuva, homens a trabalhar - ainda era possível. A segunda, localizada no presente, é a ausência de felicidade. A anáfora das expressões "o pôr do sol" e "o pôr do sol em espinho" indica que o eu lírico, que aqui é o sujeito coletivo, se debate na presença de uma realidade que não é a ideal, no sentido de desejada, e que se estabelece diante da falta da realidade almejada (o pôr do sol autêntico). Para identificar o mundo a que se refere o poema devemos necessariamente desvendar estas duas expressões. O poeta, então, nos fornece algumas chaves que nos possibilitarão, como ele mesmo diz, abrir o mundo. A expressão "conviver com os Medicis", a menção a Antero de Quental ${ }^{5}$ e o verso "sobre restos de inquietação visível em bilhetes de eléctrico" parecem ter esta função. A primeira sugere um ambiente autoritário em que os indivíduos estão submetidos a um poder. A segunda questiona se Antero, na sua época, poderia ter pressentido que as coisas se encaminhavam para este pôr do sol em espinho, para este ambiente repressor. A terceira vem sugerir o nervosismo, a inquietação e a insegurança produzidos pelo meio. Sabemos que "o pôr do sol" é o momento em que houve felicidade - "O pôr do sol em espinho é termos sido felizes" - e que se define em oposição ao pôr do sol em espinho (o presente). O que neste poema vem perturbar a nossa percepção habitual da linguagem é a predicação atribuída ao pôr do sol, a qual, na esfera do sentido literal, não se aplica a este objeto. Mas não estamos na esfera da literalidade. Quando se trata de poesia, as relações entre as palavras se estabelecem com base em outros princípios. $\mathrm{O}$ próprio poeta explica, em parte, como isso ocorre:

A palavra de poesia é a palavra na medida em que metafórica. Na medida em que se analisa na transposição do significado normal - outro problema seria saber se também natural - de um termo para outro, por virtude de uma relação de semelhança que se subentende. É metafórica porque dá uma nova forma a uma realidade natural, sensível ou afetiva (BELO, 1969: 98).

No caso da expressão "o pôr do sol em espinho", foi endereçada ao pôr do sol uma característica que não lhe pertence: a capacidade de ferir. Ao proceder desta maneira, o poeta rompe com as relações estáticas de vizinhança entre as palavras e obriga o leitor a ir em busca da realidade oculta por trás do "pôr do sol em espinho", por trás da metáfora. Ou melhor, impulsiona o leitor a desvendar o mundo para o qual esta figura aponta.

Neste ponto, é oportuno recordarmos Paul Ricoeur, que se posiciona contrário à ideia de Frege - o discurso literário não teria denotações, estas só estariam presentes no discurso científico - sustentando que o discurso literário expõe uma denotação de segunda ordem, atingida por meio da suspensão da denotação da primeira ordem do discurso. Desse modo, a obra literária manifesta o mundo (aponta para o mundo) "sob a condição de ser suspendida a referência do discurso descritivo" (RICOEUR, 1983: 330).

Assim, no poema "Literatura Explicativa", a expressão "o pôr do sol" deixa de designar o fenômeno de transição do dia para a noite e passa a fazer referência ao espaço. Pelas ligações que mantém com outros termos do poema, podemos dizer que se trata de um espaço no qual os indivíduos estão submetidos a um poder, um poder que aniquila de tal modo que não sobra nada. Tudo é ausência e desolação. Mas o sujeito poético faz

4 Nas obras publicadas a partir de 1972, como refere Ribeiro (2004), Ruy Belo procede à eliminação dos sinais de pontuação e das maiúsculas para grafar o nome de Deus e todos os nomes próprios. Os textos anteriores a esta data foram revisados.

5 Antero, integrante da Geração de 1870, foi um dos fundadores do Partido Socialista Português. Escritor comprometido com o destino do seu país, acreditava ser possível renová-lo através da literatura. 
questionamentos - entre eles, “A quem / passamos este sol? -, que parecem cobrar a participação do leitor e (nos arriscamos a afirmar com base no título do poema) cobrar respostas e/ou perguntas da própria poesia, uma vez que é por meio dela que se aborda o real. Real que na poesia se configura através da metáfora viva, a qual, como definiu Ricoeur (1983), é o resultado de um processo que, ao torcer o sentido literal das palavras, tensiona a linguagem e obtém a inovação semântica. É dessa maneira, conduzindo-nos a um mergulho ainda mais profundo no texto literário, que o poeta nos fala do Portugal da sua época. Assim, a paisagem de opressão e infelicidade, produzida pela associação da metáfora "o pôr do sol em espinho" com imagens que traduzem a falta de liberdade, aponta para a realidade portuguesa do Estado Novo.

No próximo poema a ser analisado, "Portugal Sacro-Profano: lugar onde", o poeta vai ainda mais fundo na representação do espaço:

Neste país sem olhos e sem bocahábito dos rios castanheiros costumadospaís palavra húmida e translúcidapalavra tensa e densa com certa espessura(pátria de palavra apenas tem a superfície)os comboios são mansos têm dorsos alvosengolem povoados limpamentetiram gente de aqui e põem-na aliretalham os campos congregam-sedividem-se nas várias direcçõese os homens dão-lhes boas digestões; cordeiros de metal ou talvez grilosque mãe aperta ao peito os filhos ao ouvi-los?Neste país do espaço raso do silêncio e solidãosolidão da vidraça solidão da chuvapaís natal dos barcos e do mardo preto como cor profissionaldos templos onde a devoção se multiplica em luzesdo natal que há no mar da póvoa do varzimpaís do sino objecto inútilúnica coisa a mais sobre estes diasAqui é que eu coisa feita de dias única razãovou polindo o poema sensação de segurançacom a saúde de um grito ao solcombalido tirito imito a dorde se poder estar só e haver casascuidados mastigados coisas sériaso bafo sobre o aço como o vento na águaPaís poema homemmatéria para mais esquecimentodo fundo deste dia solitário e tristeapós as sucessivas quebras de calorantes da morte pequenina celular e muito pessoalnatural como descer da camioneta ao fim da ruaneste país sem olhos e sem boca

(BELO, 2004: 259)

O poeta busca o título do poema - Portugal Sacro-Profano - em um catálogo alfabético, de todas as freguesia dos reinos de Portugal e Algarve, publicado em 1767. Daí que fique nítido desde o princípio que o país onde os indivíduos não devem ver e são impedidos de falar é Portugal. Aliás, o verso de abertura do texto é também o de fechamento, o que demonstra o predomínio de uma atmosfera de cerceamento da liberdade. Vale lembrar que o Estado Novo tinha o poder de silenciar: seja através da censura às publicações, seja através da PIDE, que reprimia qualquer sinal de oposição ao salazarismo. Para que o Estado tivesse total controle sobre os indivíduos era conveniente que tudo estivesse domesticado, como notamos no segundo verso.

No terceiro verso, sem que isto seja marcado por pontuação, há a interrupção da descrição do país e seguem-se versos que explicam as palavras "país e "pátria". Notamos, na palavra "país", uma ambivalência. Ela vai assumindo características da água (úmida e translúcida) e, ao mesmo tempo, adquire certa espessura, solidez (tensa/ densa). Neste caso, as rimas internas reforçam a vizinhança semântica. $\mathrm{O}$ eu lírico demonstra preferência pela palavra país, o que nos faz recordar uma passagem de Na senda da poesia, onde Ruy Belo (1969), quando questionado se não aceitava o conceito de pátria, afirma que a resposta está no poema "Lugar onde", da série Portugal Sacro-Profano, e que também estava em Antônio Nobre, poeta realista que encerrara um soneto com o verso: "Amigos que desgraça nascer em Portugal". Ruy Belo diz que gosta da palavra país, pois na palavra pátria há um certo imperialismo, algo que coloca o Estado acima do indivíduo. Não é demais lembrar o peso da palavra pátria na ideologia do regime ditatorial, que tinha entre seus lemas: "Deus, 


\section{Conexão Letras}

Pátria, Família”. Por isso, o alerta: “(pátria de palavra apenas tem a superfície)". É como se estivesse sendo utilizada para encobrir a realidade e a serviço de interesses impuros.

Na sequência, surgem os comboios, os quais são definidos por meio de adjetivos - mansos / alvos - e substantivos - cordeiros de metal / grilos - que expressam que são inofensivos. Por outro lado, a eles são atribuídas ações bruscas, violentas: engolem, tiram, retalham. Na verdade, estes comboios que se alimentam de homens, como sugere o verso "que mãe aperta ao peito os filhos ao ouvi-los?", podem ser os que recrutam soldados para o serviço militar obrigatório na África. Vale ressaltar a rima ${ }^{6}$ em "grilos" e "ouvilos", versos que contém uma sinestesia, e que encerra uma ironia: se os comboios são tão inofensivos por que as mães, sabendo da sua aproximação, agarram-se aos filhos?

A anáfora "Neste país" dá continuidade à descrição do espaço. Agora, trata-se do lugar onde os indivíduos não se comunicam, são solitários. Seguem alusões à história e à cultura: a vocação marítima do país, a religiosidade e o hábito de vestir-se de preto. Neste ambiente de automatismos e silêncio, silêncio perturbado apenas pelo ruído do sino, é que o eu lírico - que, a esta altura, se assume no discurso literário - vai polindo o poema. Bem, aqui nos deparamos com a concepção do poeta sobre o modo como se processa a criação literária: o polimento do poema oposto à ideia de que a poesia é fruto da inspiração ${ }^{7}$. Somente o trabalho contínuo sobre a palavra (coisa feita de dias), neste ambiente de insegurança, produz no poeta uma sensação de segurança. Apesar disso, a sua dor de homem solitário e consciente é verdadeira. Neste momento, o poeta emprega palavras que indicam enfermidade: combalido / tirito, até chegar à ação principal: imito a dor. É de se notar que a assonância - a repetição do "i" em posição tônica - traz a sensação de sofrimento, de dor. Entretanto, o labor poético se processa de forma lúcida, com a saúde de um grito ao sol.

O verso "País poema homem", que, aliás, contém a aliteração ${ }^{8}$ presente em todo o poema, pode sugerir que é o modo de ser do país o responsável por fornecer o conteúdo para o poema e ao poeta cabe, através do trabalho sobre a palavra - com a alma dilacerada, mas com a saúde de um grito ao sol -, intensificar a realidade dando-lhe forma artística. Mas tudo isso - o sofrimento, a realidade do país, o poema - é matéria para esquecimento em um país em que, domesticados, todos estão morrendo aos poucos.

Ruy Belo dizia que a vida era matéria de poesia: "O poeta deve cantar a vida, apesar de a vida ser uma loucura. Mas nenhuma outra coisa lhe é dada para glosarmos o que cantamos algures" (BELO, 1969: 25). Consequentemente, a realidade asfixiante de Portugal não poderia deixar de ser submetida ao trabalho sobre a palavra e ao olhar crítico do poeta. Olhar crítico que, antes, no poema "O maná do deserto", já dera mostras do seu alcance:

Aves tão numerosas como as areias do mar
vieram até nós sobre as dunas a voar
traziam pendurado o grande véu da sombra
que cobriria os nossos ínfimos cuidados
e aboliria até os reais problemas quotidianos

6 O poema, como é possível perceber, apresenta mais rimas internas do que externas.

7 A criação artística como fruto da inspiração, do delírio e da falta de razão, está presente no Íon, um diálogo da juventude de Platão. Neste diálogo, Sócrates interroga ao rapsodo Íon por que ele afirma ser capaz de falar sobre Homero, mas quando se trata de falar sobre outros poetas, ele não apenas diz não ser capaz como confessa que cochila. Sócrates prova a Íon que a sua atuação não é arte nem depende do conhecimento, - se fosse arte, ele seria capaz de falar sobre outros poetas - mas da inspiração. O mesmo ocorre com todos os poetas: a criação poética se processa em um momento de ausência da razão, de possessão, de inspiração divina. "O poeta é coisa leve, e alada, e sagrada e não pode poetar até que se torne inspirado e fora de si, e a razão não esteja mais presente nele" (PLATÃO, 2007: 33).

8 A repetição da consoante $\mathrm{P}$ aparece já no título do poema. 
que ainda não há muito a grande arte desconhecia

Foi a tantos anos como as areias do mar

foi no tempo dos nossos pais talvez mesmo no dos avós

$\mathrm{O}$ sol escureceu e não se ouviu a voz

de nenhum de nós mais de um metro em redor

Invadia-nos um íntimo torpor

que ao contrário da voz a todos se comunicava

E cada um em volta a medo perguntava:

Que aves serão estas que decepam quase as árvores

e nós vemos passar e ficar só nos versos dos poetas?

Um leitor da bíblia falou de codornizes

um cinéfilo dos pássaros de hitchcock

um outro garantiu que havia de saber no freixial

Todos tinham razão porque foi há muitos anos

Lembro-me agora que foi no tempo dos hebreus

e ainda era vivo não apenas deus ${ }^{9}$

como também o homem que escapou de tanta guerra

para morrer às mãos dos literatos

Aves tão numerosas como as areias do mar

vieram até nós sobre as dunas a voar

$\mathrm{E}$ a beira-mar à sombra dos pinheiros longe ou perto

todos nós comemos do maná do deserto

(BELO, 2004: 258).

Outro poema de versos livres, sem maiores preocupações com rimas e tendendo à narratividade. De fato, trata-se da "narrativa" de um acontecimento: a chegada das aves misteriosas. Na tentativa de esclarecer a origem das aves, são arroladas duas hipóteses - codornizes e os pássaros de Hitchcock -,o que, em virtude da positividade da primeira e da negatividade da segunda, dota estas aves de uma ambivalência. Ora, os pássaros de Hitchcock eram ameaças terríveis, ao passo que as codornizes , na Bíblia, eram dádivas divinas. Estas duas alusões a outros textos se integram em uma estratégia que consiste em mobilizar outras vozes, outras escritas, para compor o poema. Tal estratégia, a intertextualidade, é uma das características mais marcantes da escrita de Ruy Belo.

Laurent Jenny (1979: 14) define a intertextualidade como um "processo complexo de assimilação e transformação de vários textos, operado por um texto centralizador, que detém o comando do sentido". Para o autor, intertextualidade é, ainda, a condição de legibilidade literária, ou seja, uma obra só pode ser compreendida se levarmos em conta as relações que mantém com outras obras. O relacionamento de uma obra com outra será caracterizado pela repetição, ou pela transformação, ou pela transgressão. Dificilmente um texto é retomado para ser citado tal qual a sua aparição primeira. Além disso, o discurso intertextual não pode ser considerado uma mera repetição, pois supõe uma mirada crítica em direção ao passado.

No poema, a intertextualidade é marcadamente bíblica. O primeiro verso dialoga com o Livro de Números ${ }^{10}$, quando o Senhor envia um vento que leva inúmeras codornas ao acampamento dos israelitas. Dialoga também, juntamente com o termo "o maná do deserto", com a passagem do Livro do Exxodo, na qual os israelitas, dois meses e meio depois da fuga do Egito, por não terem o que comer, se revoltam contra Moisés e contra Deus. Então, o Senhor envia-lhes codornas para comerem à tarde e o maná para comerem

9 Para Ribeiro (2004), este verso condensa o sentido de todo o poema e expressa o cepticismo religioso dos católicos que romperam com a Igreja.

10 Bíblia Sagrada, Números, cap. 11, 31. 


\section{Conexão Letras}

pela manhã. Durante quarenta anos os israelitas puderam se alimentar do maná, até que chegaram à fronteira de Canaã. Isto posto, percebemos que o intertexto ${ }^{11}$ extrai do texto a atmosfera de carência, de necessidade, que as codornizes e o maná devem suprir. Nesse sentido, pelo diálogo com as passagens da Bíblia, as aves viriam como uma promessa, algo benfazejo: "aboliria até os reais problemas quotidianos". Na sequência, o acontecimento causa inquietação e torpor nas pessoas. Cabe ressaltar a ligação - sugerida pela assonância - entre "ínfimos cuidados" e "íntimo torpor": o mesmo evento que tornaria os indivíduos despreocupados os impede de agir.

A anáfora do verso "aves tão numerosas como as areias do mar" reforça a presença do texto bíblico e, somada aos dois versos finais, aponta para um momento em que Portugal foi glorioso. Isto porque a expressão "à sombra dos pinheiros" pode ser uma alusão ao fato de os portugueses terem plantado pinheiros para construir caravelas. Se for assim, a memória das conquistas alimentou os portugueses do mesmo modo que o maná alimentou os israelitas. Mas acreditamos que o olhar crítico de Ruy Belo foi ainda mais arguto. Assim, é relevante lembrarmos a função ideológica da exaltação do passado histórico e do império colonial português no salazarismo. Se analisamos por este ângulo, Portugal é o deserto onde os portugueses, com inúmeras carências, sobrevivem do passado.

Pelo exposto, notamos que o poeta retoma outros textos, mas os reveste de um novo sentido. Para Jenny, o discurso intertextual, por estar composto não mais por palavras, mas pelo já dito, adquire o status de um super discurso. Desse modo, o texto citado, que "já não fala, é falado" (JENNY, 1979: 22), carrega a sua carga semântica, conserva o seu sentido primeiro, mas também, ao ser assimilado pelo intertexto, se reveste de uma nova significação, ampliando, e muito, as possibilidades de leitura do intertexto. Jenny comenta, ainda, que o uso intertextual dos discursos corresponde sempre a uma vocação crítica, lúdica e exploradora. Vocação que Ruy Belo, como demonstram os poemas "Aos Homens do Cais" e "Os Estivadores”, possuía.

\footnotetext{
Plantados como árvores no chão ao alto ergueis os vossos troncos nus e o fruto que produz a vossa mão vem do trabalho e transparece à luz

Nenhum passado vale o dia-a-dia

Sonho só o que vós me consentis

Verdade a que de vós só irradia

- Portugal não é pátria mas país

(BELO, 2004: 267).
}

Neste poema de duas quadras com rimas alternadas, podemos perceber ecos de Cesário Verde - que, em "Sentimento de um ocidental", cantara as varinas e seus troncos varonis ${ }^{12}$ - e de Camões - pelo verso "Nenhum passado vale o dia-a-dia". A aliteração do "S" confere um certo ritmo ao texto, que se coaduna com a ideia de coletividade: os homens do cais, cujo trabalho é reconhecido. O primeiro verso da segunda quadra quebra o ritmo anterior e expressa a visão disfórica em relação ao passado. Não se trata, agora, de cantar e sonhar com os feitos gloriosos de varões assinalados, mas de encarar a verdade que emana dos trabalhadores do cais: "Portugal não é pátria mas país". Verificamos, aqui, a dissolução da identidade entre pátria e país. Além disso, o poeta nega a Portugal o

11 Texto absorvendo outro(s) texto(s).

12 "E num cardume negro, hercúleas, galhofeiras, / Correndo com firmeza, assomam as varinas. [...] Vêm sacudindo as ancas opulentas! / Seus troncos varonis recordam-me pilastras; [...]" (CESÁRIO VERDE, 1998: 79). 
estatuto de pátria. Em consonância com este verso está a afirmação de Ruy Belo em uma entrevista: “'A minha pátria é a Língua Portuguesa' gostaria de ter dito eu, mas disse-o Fernando Pessoa" (BELO, 1969: 41).

No poema "Os Estivadores"13 também ocorre a exaltação do trabalho do homem simples, com o qual o eu lírico se sente irmanado:

\begin{abstract}
eles são a eterna divindade
e o que antes era pura linfa

é o que sobra agora da cidade

Vede como alheios a tudo o resto compram com o suor a claridade e rasgam com a decisão do gesto o muro oposto pela gravidade
\end{abstract}

Onde outrora houve o deus e houve a ninfa

Ode marítima é que chamo à ode escrita ali sobre a pedra do cais A natureza é certo muito pode mas um homem de pé pode bem mais

(BELO, 2004: 280).

Todas estas quadras convocam outros textos. Na primeira, como podemos inferir pelos versos "Onde outrora houve o deus e houve a ninfa / eles são a eterna divindade", o diálogo é com Camões. Na segunda, o verso "compram com o suor a claridade" nos remete ao Gênesis, quando, depois de o homem ter comido do fruto proibido, Deus afirma que ele será castigado e diz: "do suor do teu rosto comerás o pão". Na terceira, o poeta convoca a "Ode Marítima" de Álvaro de Campos, entretanto, ao passo que o heterônimo de Pessoa exalta a natureza, Ruy Belo enaltece o homem. Neste caso, não se trata do homem curvado, subjugado, mas do homem de pé, imagem recorrente na poesia deste autor, como se vê no texto "Aos homens do cais": "ao alto ergueis os vossos troncos nus". Representá-los desta maneira é coerente com a finalidade do poema - exaltar - inclusive reforçada pela menção à ode.

A análise demonstra que Ruy Belo constrói os seus poemas a partir do legado da tradição literária, se beneficiando, assim, das heranças do passado. Desse modo, o texto se converte no espaço em que se reúnem diversas escrituras: um verdadeiro tecido de citações, que acolhe a voz dos precursores - Camões, Cesário Verde e Pessoa - e as marcas deixadas no poeta pela leitura da Bíblia. Tal maneira de se relacionar com os textos lidos é confirmada por Ruy Belo (1969) ao afirmar que somente o poeta dotado de musa própria pode consentir influências e que ler alguém e não lhe ficar devendo nada é a maior decepção possível. Além disso, para ele, a influência é um local de confronto e um meio de convívio, sendo a poesia o espaço de que dispõe o poeta para conviver com os seus contemporâneos e ouvir a voz dos antigos.

As afirmações do poeta português dialogam ${ }^{14}$ com as de T. S. Eliot (1962), no artigo "A tradição e o talento individual". No texto em questão, que data de 1919, Eliot já apontava a importância da presença da literatura anterior na constituição de um texto. Opondo-se à tendência vigente nos estudos literários - buscar, na obra de um autor, aquilo

$13 \mathrm{O}$ poema possui cinco quadras de rimas alternadas. Para a finalidade da análise aqui pretendida, julgamos prescindível reproduzi-lo na integra.

14 Quando esteve em Roma, entre 1956 e 1958, Ruy Belo conheceu o jovem poeta chileno Ibañez-Langlois, com quem falou muito a respeito de literatura e dos ensaios de Eliot. 
que o diferencia dos seus predecessores, o que é único -, o crítico sugere que as páginas mais significativas da literatura de um escritor são exatamente aquelas em que se percebe a presença dos poetas mortos. A tradição, para Eliot, depende do sentido histórico, ou seja, da consciência que o escritor tem não apenas do que representou o passado, mas do que ele representa, da sua presença. É este sentido histórico que impele o "homem a escrever não apenas com a sua própria geração no sangue, mas também com um sentimento de que toda a literatura européia desde Homero, e nela a totalidade da literatura da sua pátria, possui uma existência simultânea e compõe uma ordem simultânea" (ELIOT, 1962: 23). Assim, um escritor não atinge o seu significado sozinho, mas através das relações que estabelece com os seus antecessores. São estas relações, já o dizia Ruy Belo (1969), que enriquecem a poesia.

Nos três últimos poemas analisados, o poeta recorre à intertextualidade para abordar o contexto histórico, social e cultural. Já vimos que Ruy Belo acreditava que o poeta deveria cantar a vida com tudo o que ela implicasse. Isso justifica o olhar desprovido de ilusões verificável em vários poemas. Entre eles, "Sexta-feira sol dourado".

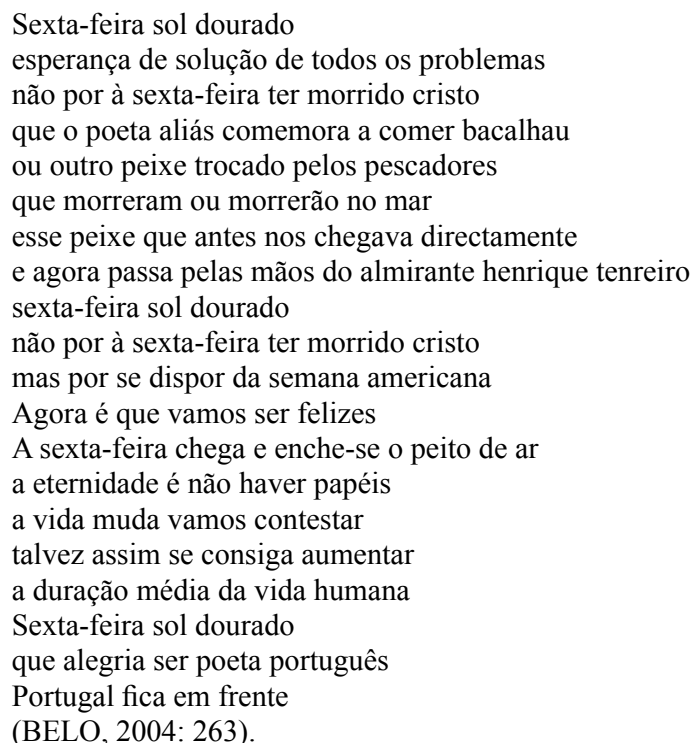

O motivo da aparente empolgação do eu lírico é a semana americana, que causa, quando chega a sexta-feira, o sentimento de liberação das solicitações, dos compromissos, das obrigações - "a eternidade é não haver papéis" 15 - e de renovação. O bacalhau funciona como pretexto para levantar duas questões sérias: a situação dos pescadores "que morreram ou morrerão no mar" e a da Administração das Pescas. Ora, quem administrava as Pescas era o Almirante Henrique Tenreiro, o qual controlava mais de trinta organizações entre cooperativas, grêmios e sociedades de seguros. Importa ressaltar que a Organização das Pescas era uma espécie de agência política do regime, onde exerciam diversas práticas ilícitas e de favoritismo. Além disso, Tenreiro auxiliou a reprimir as mobilizações do movimento estudantil e atuou na repressão às greves, empregando nestes assuntos funcionários da Organização das Pescas. Defensor do Estado Novo, o Almirante combatia todos os que lhe fossem hostis.

15 Um jogo com a ideia de que Cristo morreu e ressuscitou para a vida eterna. Aqui, vida eterna é apenas não ter obrigações. 
A introdução destas informações alarga as possibilidades de leitura do texto. $\mathrm{Na}$ sequência, o verbo "contestar" sugere a necessidade da revolta. Contudo, o aparente otimismo vem acompanhado de uma ironia amarga: "talvez assim se consiga aumentar / a duração média da vida humana". Ironia que persiste no verso "que alegria ser poeta português" e que se deve provavelmente ao fato de Portugal ser um país provinciano ${ }^{16}$, com um elevado índice de analfabetismo e atrasado em relação a outros países ocidentais.

O fato de "saber-se homem e responsável pela sua consciência e pela consciência dos outros" originará o pacto com todos os sofredores no poema "No Way Out". Consciente dos problemas que assolam a sua terra, sabe também que os males estão em toda a parte. Por isso, se solidariza com o sofrimento de todos:

Não há país que não seja meu

em qualquer parte morro pois sou mortal

mas aproveito a força da rima

para dizer que a minha rua é beavar canal

(BELO, 2004: 274).

O poeta tanto é afetado pela dor do outro que, como comprovam os dois últimos versos, isso transparece na sua escrita. Uma atitude distinta encontramos no início do poema "Os Cemitérios Tributários":
Ainda que aquela unha arranhe a pedra de jaspe não importa não é minha não me dói por isso o chispe
Por isso quem quiser asse-o que eu vou andar de barco e empregar assim o ócio que vem comigo de berço
Vou à vela vem o vento e eu grito viva o vício e mesmo este ar eu minto e dou-lhe o tom violáceo
Do jogo ninguém me livra pois caio nele de borco e palavra por palavra assim alinho o meu verso (BELO, 2004: 271).

Nestas quadras as rimas alternadas se fazem por meio da repetição das consoantes que seguem as sílabas tônicas. O eu lírico apresenta a sua posição logo na primeira estrofe: a indiferença em relação à dor do outro. Nesta parte do poema, encontramos a ambiguidade na palavra "chispe", que tanto pode significar "pé de porco" como o raspar da unha na pedra. Apesar de o verso seguinte, com o verbo assar, aparentemente resolver a ambiguidade, o leitor se vê envolvido em um grande jogo. De qualquer modo, independente do que ocorra ao outro, o eu lírico seguirá sua rotina: vai andar de barco. A

$16 \mathrm{O}$ conservadorismo do regime político, com o temor de que a modernização suplantasse os valores religiosos e culturais da nação, tentou controlar o processo de desenvolvimento e, assim, contribuiu para o atraso português. 
equivalência sonora entre as palavras "barco" e "berço" e o paralelismo existente entre os dois versos sugerem que o eu lírico é alguém que não precisa trabalhar. Todavia, a quadra seguinte começa a demonstrar - com o verso "e mesmo este ar eu minto" - que não se trata desse tipo de ócio, ou melhor, que o vício do eu lírico não é o ócio de andar de barco. A recorrência da forma fônica nas palavras "barco" / "berço" e "vício "/ "verso" nos impulsiona a interpretar a expressão "andar de barco" como metáfora do fazer poético. Assim, o poeta se entrega ao jogo da criação como quem se entrega a um vício. Neste caso, o paralelismo entre "vou andar de barco" e "caio nele de borco" reforça a nossa leitura. Leitura possível graças à captura do sentido no invólucro sonoro. A equivalência semântica induzida pela equivalência fônica, como observa Ricoeur (1983), origina a ambiguidade, que altera profundamente a função referencial. Desse modo, na poesia, a supremacia da função poética sobre a referencial não elimina a referência, mas torna-a ambígua. É neste jogo da ambiguidade que o leitor é convidado a mergulhar, jogo no qual o poeta nos conta que a sua literatura é construída a partir do fingimento e no qual finge ser indiferente às dores alheias.

Já vimos que Ruy Belo é influenciado pelos problemas sociais do seu tempo, mas não pratica uma poesia panfletária. Apesar de Portugal ser uma das suas dores, o escritor não expressa, na sua poesia, apenas a insatisfação e o desacordo em relação ao país. Em certos momentos é possível vislumbrar uma esperança: o Portugal futuro descrito através de imagens puras:

O portugal futuro é um país
aonde o puro pássaro é possível
e sobre o leito negro do asfalto da estrada
as profundas crianças desenharão a giz
esse peixe da infância que vem na enxurrada
e me parece que se chama sável
Mas desenhem elas o que desenharem
é essa a forma do meu país
e chamem elas o que lhe chamarem
portugal será e lá serei feliz
Poderá ser pequeno como este
ter a oeste o mar e a espanha a leste
tudo nele será novo desde os ramos à raiz
À sombra dos plátanos as crianças dançarão
e na avenida que houver à beira-mar
pode o tempo mudar será verão
Gostaria de ouvir as horas do relógio da matriz
mas isso era o passado e podia ser duro
edificar sobre ele o portugal futuro
(BELO, 2004: 264).

Há três tempos marcados no poema: o presente - tempo do peixe que vem na enxurrada; o passado - quando se ouviam as horas do relógio da matriz e o futuro - o país do puro pássaro, das crianças desenhando, o país em que tudo será novo.

A rima interna entre "futuro" e "puro" sugere que Portugal será o lugar de uma inocência possível. Além disso, a expressão "puro pássaro" demonstra também a possibilidade de liberdade. O paralelismo entre os versos "mas desenhem elas o que desenharem" e "chamem elas o que lhe chamarem" concorre para a conclusão - "Portugal será e lá serei feliz" - que é a afirmação de uma esperança $a^{17}$, esperança asseverada pela rima entre

17 A aliteração presente no texto - a repetição da consoante $\mathrm{P}$-, além de concordar com o título, confirma a 
"país" e "feliz". Por outro lado, a rima entre "raiz" e "matriz" sugere a necessidade de uma mudança profunda em Portugal. Por isso, seguir com as práticas do passado - aqui representadas pelo sino da matriz - seria arriscado.

Enquanto no poema acima, apesar da advertência final, prevalece o otimismo, em "Cinco palavras cinco pedras" o tom é de derrota, já que, para escrever o poema, o poeta dispõe somente das palavras desalento, desolação, prostração, desânimo e desistência:

Antigamente escrevia poemas compridosHoje tenho quatro palavras para fazer um poemaSão elas: desalento prostação desolação desânimoE ainda me esquecia de uma: desistênciaOcorreu-me antes do fecho do poemae em parte resume o que penso da vidapassado o dia oito em cada mêse delas vem a música precisapara continuar. Recapitulo:desistência desalento prostação desolação desânimoAntigamente quando os deuses eram grandeseu sempre dispunha de muitos versosHoje só tenho cinco palavras cinco pedrinhas

(BELO, 2004: 272).

São apresentadas duas situações: o passado, quando o sujeito lírico dispunha de muitas palavras para escrever, que, nesse sentido, é ilustrado pela extensão do verso, e o presente, momento em que possui apenas cinco palavras. A anáfora de "antigamente" cria um paralelismo entre os versos. Assim, quando os deuses eram grandes, havia segurança e era possível escrever poemas longos. Hoje, para o homem que foi desamparado pela crença em Deus e não substituiu por nada, há somente cinco palavras, as únicas que a hora absurda lhe fornece para escrever o poema. Logo, em face da impossibilidade de cantar de outro modo, é a desistência concentrada nestas cinco pedrinhas, talvez equivalentes a um universo ${ }^{18}$, que gera o poema.

\section{Considerações finais}

Produto das marcas que o mundo causa no sujeito, o poema se torna um espaço de reação, a maneira encontrada pelo poeta para interpelar a realidade adversa. É nesse sentido que podemos falar de agência política na poesia de Ruy Belo. Esta poesia enquanto reação às injustiças, apresenta Portugal como o país da opressão, do silêncio, da solidão e da infelicidade, questiona o poder estabelecido e seus mecanismos ideológicos, encara a situação do país sem ilusões e toma partido dos oprimidos. Enquanto manifestação de uma esperança, ela acena com a possibilidade de um futuro melhor, mas alerta para a necessidade de profundas transformações. Além disso, por trás da dor imensa experimentada pelo eu lírico, ela faz transparecer o sofrimento dos outros indivíduos, aos quais dá voz.

Apesar de se posicionar contrário à utilidade da poesia, Ruy Belo (1969) pensava que o escritor devia transmitir uma mensagem válida para os leitores. Essa convicção surge nos escritos do poeta aliada à busca incessante do domínio da expressão poética. Ambos os aspectos, recordemos, estão presentes no poema "Lugar onde". Ali, o eu lírico nos fala de um espaço no qual os indivíduos estão submetidos ao silêncio. A única segurança possível, nessas condições, advém do ato de polir o poema. Concluímos, então, que o poeta não se recusa a abordar a realidade - e aí reside a importância da sua mensagem - e, ao mesmo tempo, por meio das associações, das equivalências, das metáforas, transforma a poesia no espaço da insubordinação. Assim, dos versos do autor de

esperança no futuro do país. Para isso também contribui a musicalidade.

18 Há um diálogo com Alberto Caeiro: "Ao anoitecer brincamos as cinco pedrinhas / No degrau da porta de casa, / Graves como convém a um deus e a um poeta, / E como se cada pedra / Fosse todo um universo / E fosse por isso um grande perigo para ela / Deixá-la cair no chão" (PESSOA, 2006: 49). 


\section{Conexão Letras}

Homem de Palavra [s], emerge a voz daqueles que foram silenciados. E Ruy Belo (1969) acreditava que o poeta devia emprestar a voz àqueles que não a possuíam. Daí que os seus versos tenham um caráter ambivalente: sejam perguntas e, ao mesmo tempo, respostas ao mundo. Por isso, e por serem construídos a partir de outros textos e de enunciados metafóricos, provocam no leitor uma dupla inquietação: a da busca do sentido, ou seja, da interpretação e a da reflexão sobre a realidade.

Ao refletir sobre a afirmação de Northop Frye - a hipótese poética é a proposição de um mundo sob o modo imaginativo, fictício -, Ricoeur coloca a seguinte questão: "Não será função da poesia suscitar um outro mundo - um mundo outro que corresponde a possibilidades outras de existir, a possibilidades que sejam os nossos mais profundos possíveis?" (RICOEUR, 1983: 342). A linguagem poética, por organizar de outro modo o real, amplia a nossa consciência e apura a nossa sensibilidade, fazendo com que passemos a ver o mundo de outra maneira. A poesia tem, então, como é sugerido no poema "Algumas proposições com crianças", a capacidade de "permitir a infância"19: outra forma de relacionamento com o que nos cerca. Por fim, através da poesia, como acreditava Ruy Belo, o poeta pode vir a conhecer-se melhor e a ajudar os outros a conhecer-se. Nesse sentido, por ter o potencial de interferir no entendimento que os indivíduos têm de si e do mundo, a poesia pode retirá-los do comodismo e impulsioná-los na direção da consciência reflexiva.

\section{Referências}

ADORNO, Theodor. Lírica e sociedade. In: BENJAMIN, Walter et al. Textos escolhidos. São Paulo, Abril Cultural, 1983.

BELO, Ruy. Palavra [s] de lugar. In: _. Homem de palavra [s]. In: . Todos os poemas. 2 ed. Lisboa, Assírio \& Alvim, 2004. v.1.

. Na senda da poesia. Lisboa, União Gráfica, 1969.

BÍBLIA SAGRADA. São Paulo, Sociedade Bíblica do Brasil, 1993.

VERDE, Cesário. O livro de Cesário Verde. Porto Alegre, Mercado Aberto, 1998.

CRUZ, Gastão. A poesia portuguesa hoje. Lisboa, Plátano Editora, 1973.

ELIOT, Thomas Stearns. Ensaios de doutrina crítica. Lisboa, Guimarães, 1962.

JENNY, Laurent. A estratégia da forma. Poétique: revista de teoria e análise

literárias; Intertextualidades, Coimbra, 1979. p. 5-49.

PESSOA, Fernando. Poemas de Alberto Caeiro. Porto Alegre, L\&PM, 2006.

PLATÃO. Sobre a inspiração poética (Íon) \& Sobre a mentira (Hipias Menor).

Porto Alegre, L\&PM, 2007.

RIBEIRO, Manuel Antônio Silva. A margem da transcendência: um estudo da poesia de Ruy Belo. Lisboa, Fundação Calouste Gulbenkian, 2004.

RICOEUR, Paul. Metáfora e referência. In: A metáfora viva. Lisboa, Rés, 1983.

ROSAS, Fernando. História de Portugal: o Estado Novo. Lisboa, Estampa, 1998.

19 "Senhor que a minha vida seja permitir a infância / embora nunca mais eu saiba como ela se diz" (BELO, 2004:282). 